\title{
Increased insulin sensitivity and upregulation of insulin receptor, insulin receptor substrate (IRS)-1 and IRS-2 in liver of Ames dwarf mice
}

\author{
F P Dominici, S Hauck ${ }^{1}$, D P Argentino, A Bartke ${ }^{1}$ and D Turyn \\ Instituto de Química y Fisicoquímica Biológicas, Facultad de Farmacia y Bioquímica, Junin 956, 1113, Buenos Aires, Argentina \\ ${ }^{1}$ Department of Physiology, School of Medicine, Southern Illinois University, Carbondale, Illinois, 62901-6512, USA \\ (Requests for offprints should be addressed to D Turyn; Email: dturyn@qb.ffyb.uba.ar)
}

\begin{abstract}
In the present study we have used hypopituitary Ames dwarf mice, which lack GH, prolactin and TSH, to investigate the consequences of the deficiency of these hormones on glucose homeostasis and on the initial components of the insulin signal transduction pathway in the liver. Ames dwarf mice displayed hypersensitivity to insulin since they maintained lower fasting glucose concentrations ( $73 \%$ of control values), had significantly reduced amounts of insulin (58\% of control values), and exhibited an increased hypoglycemic response to exogenous insulin. Probably as a result of reduced insulin production, Ames dwarf mice displayed intolerance to glucose. The insulin-stimulated phosphorylation of the insulin receptor (IR) tended to be increased in the liver of Ames dwarf mice, while IR receptor protein content was increased by $38 \%$. Insulin-stimulated phosphorylation of
\end{abstract}

insulin receptor substrate (IRS)-1 and IRS-2 was increased by 61 and $72 \%$ respectively, while IRS-1 and IRS-2 protein levels were increased by 76 and $95 \%$. The insulin-stimulated association of the p 85 regulatory subunit of phosphatidylinositol (PI) 3-kinase with IRS-1 was increased by $28 \%$, but unaltered with IRS-2. Interestingly, while the insulin-stimulated phosphotyrosinederived PI 3-kinase activity was not changed, insulin-stimulated protein kinase B activation was increased by $41 \%$ in this tissue. These alterations may account for the insulin hypersensitivity exhibited by these animals. The present findings in long-lived Ames dwarf mice add to the evidence that insulin signaling is importantly related to the regulation of aging and life span. Journal of Endocrinology (2002) 173, 81-94

\section{Introduction}

Insulin regulates glucose, lipid and protein metabolism in its target organs including liver, muscle and fat (Cheatham \& Kahn 1995). The master switch of the insulin signaling pathway is the insulin receptor (IR), a protein tyrosine kinase that, when activated by insulin binding, undergoes autophosphorylation and phosphorylates several intracellular proteins including insulin receptor substrate (IRS)-1 and IRS-2 (White 1997). Consequences of disruption of IRS-1 and IRS-2 in mice suggest that these proteins have a crucial role in the coordination of the effects of insulin on peripheral metabolism (Araki et al. 1994, Tamemoto et al. 1994, Withers et al. 1998). Following tyrosine phosphorylation, IRS-1 and IRS-2 function as adaptors, providing docking sites for various SH2 domain-containing proteins, thus linking the IR to its final biological actions (White 1997). The enzyme phosphatidylinositol (PI) 3-kinase is one of the best characterized SH2 domain-containing proteins. When tyrosine phosphorylated, IRS-1 and IRS-2 bind the p 85 regulatory subunit of PI 3-kinase, leading to activation of this enzyme (Backer et al. 1992, Sun et al. 1995). It has been well established that this is a central event in the realization of insulin metabolic effects (Shepherd et al. 1998). Protein kinase B (Akt) is a well-documented downstream target for PI 3-kinase and has been implicated in mediating certain insulin responses, such as insulininduced glucose uptake and glycogen synthase activation (Coffer et al. 1998). Akt is activated by phospholipid binding and phosphorylation at two regulatory sites, Thr308 and Ser473 (Alessi et al. 1996).

Growth hormone $(\mathrm{GH})$ and prolactin (PRL) are known to counteract the action of insulin in carbohydrate metabolism (Landgraf et al. 1977, Davidson 1987). In humans and animals, glucose intolerance, insulin resistance and hyperinsulinemia are associated with excess of GH (Rizza et al. 1982, Ader et al. 1987, Davidson 1987) or PRL (Landgraf et al. 1977, Schernthaner et al. 1985, Foss et al. 1995, Reis et al. 1997), while deficiency of these hormones leads to increased insulin sensitivity, decreased insulin secretion and hypoglycemia (Hopwood et al. 1975, 
Bougneres et al. 1985, Daugaard et al. 1999). GH and PRL have been shown to promote tyrosine phosphorylation of IRS-1 and IRS-2 and their association with PI 3-kinase both in vitro (Souza et al. 1994, Argetsinger et al. 1995, Ridderstråle et al. 1995, Berlanga et al. 1997) and in vivo (Yamauchi et al. 1998, Thirone et al. 1999). These results suggest that $\mathrm{GH}$ and PRL share some of the signaling molecules used by insulin, and that their metabolic effects may be attributed, at least in part, to crosstalk with insulin.

In a previous study we have used mice lacking $\mathrm{GH}$ receptors to investigate the consequences of the absence of $\mathrm{GH}$ action on insulin sensitivity and insulin signaling (Dominici et al. 2000). As an extension of this study, we have now investigated the effects of combined deficiency of $\mathrm{GH}$ and PRL and thyrotropin (TSH) on insulin sensitivity and insulin signaling. To this end, we have used Ames dwarf mice, which are characterized by primary pituitary deficiency consisting of the absence of, or extreme reduction in, anterior pituitary cells which produce GH, PRL and TSH (Schaible \& Gowen 1961, Andersen et al. 1995). Owing to a lack of TSH, they are also hypothyroid (Bartke 1979). Postnatal growth is greatly reduced in these animals and adult body weight size is approximately one-third to one-half of normal. A state of enhanced insulin sensitivity evidenced by normal or reduced insulin levels concomitant with hypoglycemia in the fed state has been reported in these animals (Borg et al. 1995). In the present study we have sought to identify proximal insulin signaling alterations in the liver of Ames dwarf mice in vivo that could explain the increased glucose response to insulin in these animals.

\section{Materials and Methods}

\section{Materials}

The reagents and apparatus for SDS-PAGE and immunoblotting were obtained from Bio-Rad (Hercules, CA, USA). Hepes, Tris, phenylmethylsulfonyl fluoride (PMSF), aprotinin, ATP, Triton X-100, Tween 20, porcine insulin, BSA (fraction V), PI and D-glucose were obtained from Sigma Chemical Co. (St Louis, MO, USA). Protein A-Sepharose $6 \mathrm{MB}$ was from Pharmacia (Uppsala, Sweden). ${ }^{125}$ I-protein A was purchased from ICN Biomedicals (Costa Mesa, CA, USA). $\left[\gamma_{-}{ }^{32} \mathrm{P}\right] \mathrm{ATP}$ was from Dupont-NEN (Boston, MA, USA). Polyvinylidene difluoride membranes were from Millipore (Bedford, MA, USA). The monoclonal anti-phosphotyrosine antibody $(\alpha \mathrm{PY}, \mathrm{PY} 99)$ and the polyclonal anti-insulin receptor $\beta$-subunit antibody ( $\alpha \mathrm{IR}, \mathrm{C}-19)$ were purchased from Santa Cruz Biotechnology, Inc. (Santa Cruz, CA, USA). The anti-rat carboxy-terminal IRS-1 antibody ( $\alpha$ IRS-1), the anti-rat carboxy-terminal IRS-2 antibody ( $\alpha$ IRS- 2 ) and the antibody to the p85 subunit of PI 3-kinase ( $\alpha$ p85) were from Upstate Biotechnology (Lake Placid, NY, USA). The phosphoplus Akt (Ser473) antibody kit, in- cluding rabbit phosphospecific and total Akt antibodies was purchased from New England Biolabs (Beverly, MA, USA).

\section{Experimental animals}

Seventy female Ames dwarf mice (Prop $1^{d f} /$ Prop $\left.1^{d f}\right)$ and 66 normal $\left(+/+\right.$ or $+/$ Prop $\left.1^{d f}\right)$ littermates, $4-5$ months of age, produced in our breeding colony were used. Animals were housed in a room with a controlled photoperiod of $12 \mathrm{~h}$ light:12 h darkness (lights on from 0600 to $1800 \mathrm{~h}$ ) and a temperature of $22 \pm 2{ }^{\circ} \mathrm{C}$. Animals were given free access to a nutritionally balanced diet (LabDiet, PMI Feeds, Inc., St Louis, MO, USA) and tap water. All animal studies were approved by the Southern Illinois University Animal Care and Use Committee.

\section{Measurement of glucose and hormone concentrations}

Fasting serum insulin concentration was determined using a solid phase RIA kit from DPC (Diagnostic Products, Inc., Los Angeles, CA, USA).

Serum glucose was measured with the glucose oxidase procedure (Trender; Sigma Chemical Co.). GH serum concentration was measured by RIA as previously described (Dominici et al. 1998). The plasma PRL circulating concentrations were measured by RIA following a previously described protocol (Chandrashekar et al. 1999). Plasma concentrations of triiodothyronine $\left(T_{3)}\right.$ and thyroxine $\left(\mathrm{T}_{4}\right)$ were determined with a commercial RIA kit (ICN Biomedicals).

All RIA measurements was performed in duplicate within the same assay. Variations between duplicate samples of less than $5 \%$ were considered acceptable. The sensitivity for these assays were: $\mathrm{GH}, 2 \mathrm{ng} / \mathrm{ml}$; PRL, $2 \mathrm{ng} / \mathrm{ml} ; \mathrm{T}_{3}, 25 \mathrm{ng} / \mathrm{dl} ; \mathrm{T}_{4}, 1 \mu \mathrm{g} / \mathrm{dl}$; insulin, $3 \mu \mathrm{IU} / \mathrm{ml}$.

\section{Glucose tolerance test}

Glucose tolerance tests were performed on animals after a $15 \mathrm{~h}$ overnight fast. Animals were injected i.p. with D-glucose ( $2 \mathrm{~g} / \mathrm{kg}$ body weight) and blood glucose values were determined before glucose injection (time zero) and 15, 30, 60 and $120 \mathrm{~min}$ after the injection in serum samples obtained by cardiac puncture from anesthetized animals. To measure insulin levels at the indicated time points after the glucose load, blood was collected, allowed to clot on ice, centrifuged and the serum frozen at $-70{ }^{\circ} \mathrm{C}$ until assayed for insulin.

\section{Insulin tolerance test}

Mice of each genotype of about the same age were fasted overnight before the study. Animals were injected i.p. 
with porcine insulin ( $0.75 \mathrm{IU}$ per kg body weight). Blood was taken immediately before insulin injection and 15, 30 and $60 \mathrm{~min}$ after the injection.

\section{Insulin administration and tissue homogenization}

Female dwarf mice and their normal siblings were starved overnight, and $15 \mathrm{~min}$ before the experiment they were anesthetized by the i.p. administration of $100 \mathrm{mg}$ sodium pentobarbital per kg body weight. After anesthesia was induced, the portal vein was exposed and 10 IU porcine insulin per $\mathrm{kg}$ body weight in normal saline $(0.9 \% \mathrm{NaCl})$ in a final volume of $0 \cdot 1 \mathrm{ml}$ were injected via this vein. Ames dwarf mice and normal mice were injected with diluent to obtain data under basal conditions. Approximately $50 \mathrm{~s}$ after injection, the liver was removed, coarsely minced, and homogenized in 10 volumes solubilization buffer A (1\% Triton, $100 \mathrm{mM}$ Tris (pH 7.4), $100 \mathrm{mM}$ $\mathrm{Na}_{4} \mathrm{P}_{2} \mathrm{O}_{7}, 100 \mathrm{mM} \quad \mathrm{NaF}, 10 \mathrm{mM}$ EDTA, $10 \mathrm{mM}$ $\mathrm{Na}_{3} \mathrm{VO}_{4}, 2 \mathrm{mM}$ PMSF, and $0.1 \mathrm{mg} / \mathrm{ml}$ aprotinin) at $4{ }^{\circ} \mathrm{C}$ as described previously (Dominici et al. 2000). Liver extracts were centrifuged at $100000 \mathrm{~g}$ for $1 \mathrm{~h}$ at $4{ }^{\circ} \mathrm{C}$ to eliminate insoluble material, and protein concentration was measured using the Bradford method.

\section{Immunoprecipitation}

Supernatants containing equal amounts of protein $(8 \mathrm{mg})$ were incubated at $4{ }^{\circ} \mathrm{C}$ overnight with $\alpha$ IR, $\alpha$ IRS- 1 or aIRS-2 (4 $\mu \mathrm{g} / \mathrm{ml}$ final concentration for all antibodies). After incubation, $100 \mu \mathrm{l}$ protein A-Sepharose (50\%, v/v) were added to the mixture. The preparation was further incubated with constant rocking for $2 \mathrm{~h}$ and centrifuged at $10000 \mathrm{~g}$ for $1 \mathrm{~min}$ at $4{ }^{\circ} \mathrm{C}$. The precipitate was washed three times with solubilization buffer A followed by boiling in Laemli sample buffer. The final precipitate was boiled for $5 \mathrm{~min}$ in $60 \mu \mathrm{l}$ reducing sample buffer (final concentrations: $62.5 \mathrm{mM}$ Tris, 10\% glycerol, 5\% 2-mercaptoethanol, $2 \%$ SDS, $0.02 \%$ bromophenol blue), and stored at $-70{ }^{\circ} \mathrm{C}$ until needed for electrophoresis.

\section{Immunoblotting}

Resolution of proteins by SDS-PAGE and Western transfer of proteins to Immobilon $\mathrm{P}$ membranes (Millipore, Bedford, MA, USA) was performed as previously described (Dominici et al. 2000). To reduce nonspecific antibody binding, the membranes were incubated for $2 \mathrm{~h}$ at room temperature in a blocking buffer composed of Tris-buffered saline-Tween 20 (TBS-T) buffer $(10 \mathrm{mM}$ Tris- $\mathrm{HCl}(\mathrm{pH} 7 \cdot 6), 150 \mathrm{mM} \mathrm{NaCl}$, and $0 \cdot 02 \%$ Tween 20 ) containing either $3 \%$ BSA (for phosphotyrosine detection) or $5 \%$ nonfat dry milk (for protein detection). The membranes were then incubated for $4 \mathrm{~h}$ at room temperature with $\alpha$ PY $(1 \mu \mathrm{g} / \mathrm{ml}), \alpha$ IR $(1 \mu \mathrm{g} / \mathrm{ml}), \alpha$ IRS-1 $(1 \mu \mathrm{g} /$ $\mathrm{ml})$ or $\alpha \operatorname{IRS}-2(1.5 \mu \mathrm{g} / \mathrm{ml})$ diluted in the corresponding blocking buffer. The membranes were subjected to four 5 min washes in TBS-T buffer and were then incubated with $3 \mu \mathrm{Ci}{ }^{125}$ I-protein A $(30 \mu \mathrm{Ci} / \mu \mathrm{g})$ in $15 \mathrm{ml}$ blocking buffer for $1 \mathrm{~h}$ at room temperature and then washed again for $60 \mathrm{~min}$ as described above. ${ }^{125}$ I-protein A bound to antibodies was detected by autoradiography using preflashed Kodak XAR film (Eastman Kodak, Rochester, NY, USA) at $-70{ }^{\circ} \mathrm{C}$ for $6-72 \mathrm{~h}$. Band intensities were quantitated by optical densitometry of the developed autoradiographs.

The amount of the p85 subunit of the PI 3-kinase in $\alpha$ IRS- 1 or $\alpha$ IRS-2 immunoprecipitates was evaluated by stripping the membranes and reblotting as previously described (Dominici et al. 2000). To determine the abundance of p85 in liver, equal amounts of solubilized proteins $(100 \mu \mathrm{g})$ were denatured by being boiled in reducing sample buffer, resolved by SDS-PAGE, and subjected to immunoblotting with ap85. Bound antibodies were detected by incubation with ${ }^{125}$ I-protein A. Quantitation of specific protein bands was performed by densitometric analysis.

\section{PI 3-kinase activity}

This determination was performed essentially as described previously (Dominici et al. 1999a, 2000). Briefly, livers of normal and Ames dwarf mice which had been injected with or without insulin were removed and homogenized in solubilization buffer B $(50 \mathrm{mM}$ Hepes $(\mathrm{pH} 7 \cdot 4)$, $137 \mathrm{mM} \mathrm{NaCl}, 1 \mathrm{mM} \mathrm{MgCl}, 1 \mathrm{mM} \mathrm{CaCl} 2,2 \mathrm{mM}$ $\mathrm{Na}_{3} \mathrm{VO}_{4}, 10 \mathrm{mM} \mathrm{Na}_{4} \mathrm{P}_{2} \mathrm{O}_{7}, 100 \mathrm{mM} \mathrm{NaF}, 2 \mathrm{mM}$ EDTA, $2 \mathrm{mM}$ PMSF, $2 \mathrm{mM}$ aprotinin, $2 \mathrm{mM}$ leupeptin, $10 \%$ $(\mathrm{v} / \mathrm{v})$ glycerol, and $1 \%$ Triton $\mathrm{X}-100)$ at $4{ }^{\circ} \mathrm{C}$. The homogenates were centrifuged at $100000 \mathrm{~g}$ for $1 \mathrm{~h}$ at $4{ }^{\circ} \mathrm{C}$, and the supernatants were incubated overnight at $4{ }^{\circ} \mathrm{C}$ with $\alpha \mathrm{PY}(5 \mu \mathrm{g})$. Immunocomplexes were collected by addition of protein A-Sepharose and incubated in a $70 \mu \mathrm{l}$ reaction containing $440 \mu \mathrm{M} \quad \mathrm{ATP} \quad(30 \mu \mathrm{Ci}$ $\left.\left[\gamma-{ }^{32} \mathrm{P}\right] \mathrm{ATP}\right)$ and $20 \mu \mathrm{g}$ PI. After $10 \mathrm{~min}$ at room temperature with constant shaking, the reaction was terminated by addition of $20 \mu \mathrm{l} 8 \mathrm{M} \mathrm{HCl}$ and $160 \mu \mathrm{l}$ methanol:chloroform (1:1). Mixtures were centrifuged and the lower organic phase applied to silica TLC plates (Merck, Darmstadt, Germany) coated with 1\% potassium oxalate. TLC plates were developed in $\mathrm{CHCl}_{3}$ : $\mathrm{CH}_{3} \mathrm{OH}: \mathrm{H}_{2} \mathrm{O}: \mathrm{NH}_{4} \mathrm{OH}(60: 47: 11 \cdot 3: 2)$, dried and visualized by autoradiography. The band corresponding to PI 3-phosphate was excised and its radioactivity was quantitated by liquid scintillation counting.

\section{Akt phosphorylation assay}

Western blot analysis of Ser473 of Akt in total liver extracts was carried out using the Phosphoplus Akt antibody kit (New England Biolabs, Inc.) according to the manufacturer's protocol. Membranes were reprobed with 
Table 1 Characteristics of Ames dwarf mice and their normal littermates. Values are means \pm S.E.M. (numbers of mice in parentheses). Blood glucose and insulin concentrations were measured after an overnight fast

\begin{tabular}{|c|c|c|}
\hline & Normal & Ames dwarf \\
\hline Body weight (g) & $27 \pm 4(16)$ & $4 \pm 2^{*}(16)$ \\
\hline Glucose (mg/dl) & $154 \pm 16(12)$ & $112 \pm 8^{*}(15)$ \\
\hline Insulin ( $\mu \mathrm{IU} / \mathrm{ml})$ & $19 \pm 5(12)$ & $11 \pm 4^{*}(15)$ \\
\hline $\mathrm{GH}(\mathrm{ng} / \mathrm{ml})$ & $14 \pm 7(12)$ & $\mathrm{ND}(12)$ \\
\hline PRL (ng/ml) & $5 \pm 2(12)$ & ND (12) \\
\hline $\mathrm{T}_{3}(\mathrm{ng} / \mathrm{dl})$ & $88 \pm 12(6)$ & ND (6) \\
\hline $\mathrm{T}_{4}(\mu \mathrm{g} / \mathrm{dl})$ & $3 \cdot 8 \pm 0 \cdot 4(6)$ & ND (6) \\
\hline
\end{tabular}

*Significantly different from normal mice $(P<0 \cdot 01)$. $\mathrm{ND}$, not detected.

a rabbit anti-Akt antibody (provided in the kit). Band intensities were quantitated by densitometric analysis.

\section{Statistical analysis}

Results are presented as means \pm S.E.M. Experiments were performed by analyzing all groups of animals in parallel. Data were analyzed with one-way ANOVA followed by the Tukey-Kramer test using GraphPad InStat version 3.00 for Windows 95 by GraphPad Software, Inc. (San Diego, CA, USA). Student's $t$-test was used when the values of two groups were analyzed. The level of significance was set at $P<0 \cdot 05$.

\section{Results}

\section{Animal characteristics}

Data on body weight, and blood glucose and insulin concentrations of the studied animals are shown in Table 1. In the fasted state, the Ames dwarf mice displayed a moderate but significant reduction in blood glucose concentrations $(73 \%$ of control values, $P<0 \cdot 01)$, whereas circulating insulin concentrations were reduced to $58 \%$ of values measured in their normal littermates $(P<0 \cdot 01)$.

As shown in Table 1, GH, PRL and thyroid hormones concentrations in Ames dwarf mice were below the detection limits for the corresponding assays used.

\section{Glucose tolerance test}

As demonstrated by an i.p. glucose tolerance test, Ames dwarf mice manifested a marked glucose intolerance (Fig. 1A). Blood glucose concentrations in the Ames dwarfs were significantly higher than those in the normals at all time points after glucose administration. After the same glucose challenge, Ames dwarf mice exhibited a severe reduction in the acute insulin secretory response at 5 and $20 \mathrm{~min}(P<0 \cdot 01$; Fig. 1B).

\section{Insulin tolerance test}

To clarify how lower glucose concentrations may exist in Ames dwarf mice despite decreased circulating insulin concentration, an insulin tolerance test was performed. Increased insulin sensitivity was observed following insulin administration in Ames dwarf mice. Blood glucose concentrations in dwarf animals were significantly lower than those detected in the normal group at all time points analyzed after insulin injection (Fig. 1C).

\section{Insulin receptor tyrosine phosphorylation and protein levels}

For analysis and presentation, the value of insulinstimulated normal mice was set as $100 \%$. Basal phosphorylation levels of the IR were comparable for normal and Ames dwarf mice ( $5 \pm 1$ vs $5 \pm 2 \%$ respectively; Fig. 2A and B). Insulin stimulation resulted in a 20 -fold increase in IR phosphorylation in liver of the normal mice. In liver of Ames dwarf mice, IR phosphorylation after insulin administration was increased to $131 \pm 27 \%$ when compared with normal mice $(n=5)$, but this apparent difference did not reach statistical significance (Fig. 2A and B). In liver of Ames dwarf mice, IR protein levels were increased to $138 \pm 18 \%$ of values measured in the normal controls $(n=10, P<0 \cdot 01)$ (Fig. 2C and D).

When the data on tyrosine phosphorylation were expressed relative to the amount of IR, there was no significant change in the level of IR phosphorylation in dwarf mice compared with the normal control group.

\section{IRS-1 and IRS-2 tyrosine phosphorylation and protein levels}

IRS-1 phosphorylation under basal conditions was similar for both groups of animals $(36 \pm 5 \%$ in the normal group and $41 \pm 18 \%$ in the Ames dwarf mice; Fig. $3 A$ and B). Insulin stimulation resulted in an approximately 3 -fold increase in both IRS-1 and IRS-2 tyrosine phosphorylation in normal mice. In dwarf mice, insulinstimulated IRS-1 phosphorylation was increased to $161 \pm 17 \% \quad(n=5, P<0 \cdot 01) \quad$ (Fig. $3 \mathrm{~A}$ and B), whereas IRS-2 tyrosine phosphorylation was increased to $172 \pm 35 \%$ compared with normal mice $(n=5, P<0 \cdot 05)$ (Fig. 4A and $\mathrm{B}$ ).

In dwarf mice, there was an increase in the levels of both proteins, as evaluated by scanning densitometry. IRS-1 protein levels were increased to $176 \pm 25 \%$ of normal values $(n=10, P<0 \cdot 05)$ (Fig. $3 \mathrm{C}$ and $\mathrm{D})$, while protein content of IRS-2 was increased to $195 \pm 12 \%$ $(n=10, P<0 \cdot 001)$ (Fig. 4C and D).

When the tyrosine phosphorylation was normalized for the content of IRS-1 and IRS-2 protein in liver, the 

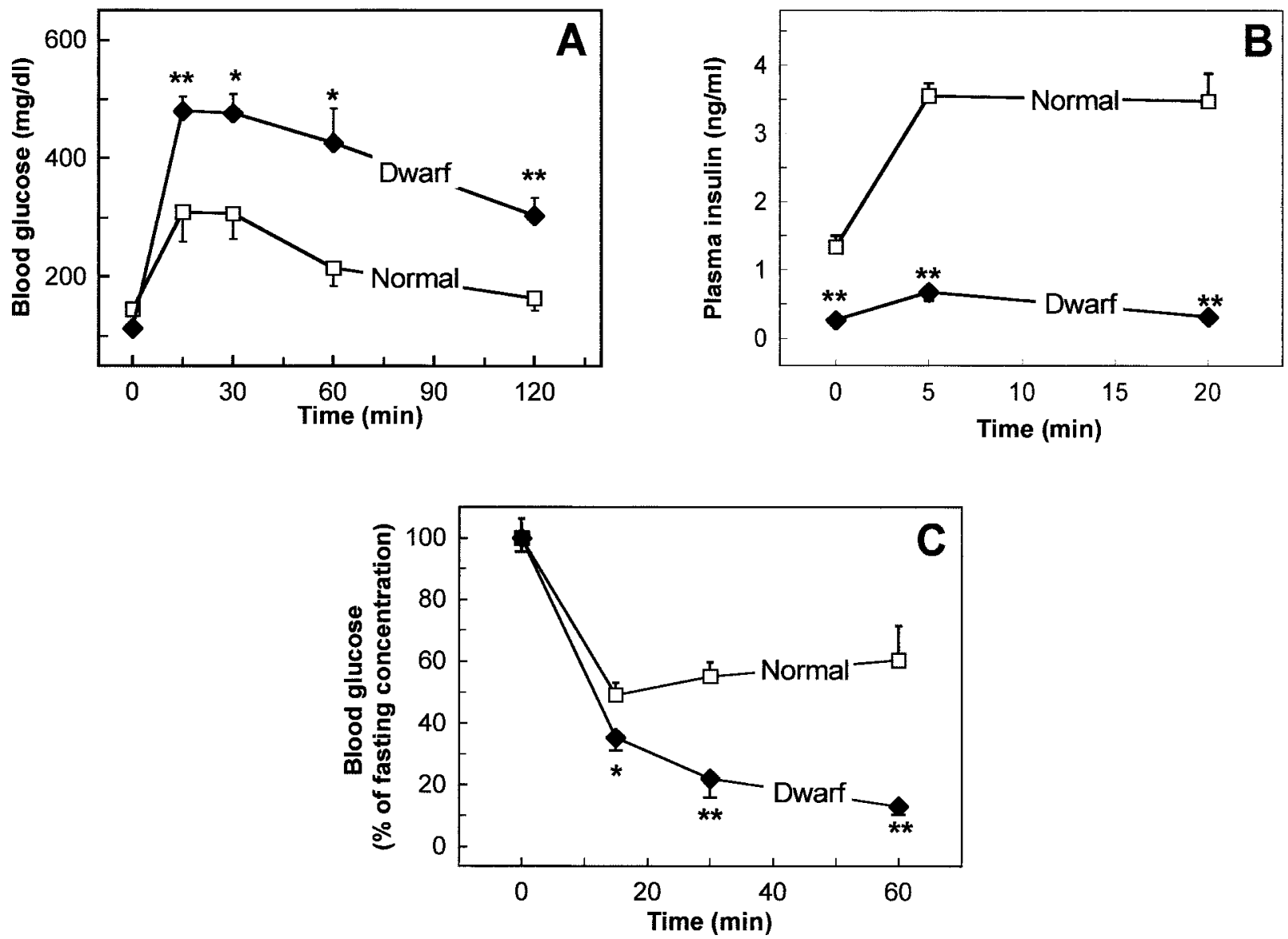

Figure 1 Analysis of glucose tolerance and insulin sensitivity. Blood glucose (A) and insulin (B) concentrations were measured before and after i.p. injection of D-glucose ( $2 \mathrm{~g} / \mathrm{kg}$ body weight) in mice fasted overnight. (C) Normal and Ames dwarf mice were injected i.p. with insulin $(0.75 \mathrm{IU} / \mathrm{kg})$ and blood glucose concentrations were determined at indicated time points. Results are means \pm S.E.M. for at least six animals per time point analyzed. ${ }^{*} P<0.05$ and ${ }^{*} P<0.01$ when compared with the corresponding value obtained in normal mice. When not presented, the S.E.M. was smaller than the symbols.

hepatic IRS-1 and IRS-2 phosphorylation in the dwarf mice was not significantly different from the values measured in normals.

\section{p85 association}

In control mice, insulin administration resulted in an almost 2-fold stimulation in the association of $\mathrm{p} 85$ with IRS-1 (Fig. 5A and B) and in a similar increase in the amount of p85 associated with IRS-2 (Fig. 5C and D). After insulin stimulation, the amount of p85 associated with IRS-1 in dwarf mice was increased to $128 \pm 13 \%$ compared with values measured in normal mice $(n=5$, $P<0 \cdot 05)$ (Fig. 5A and B). When compared with the normal control group, the amount of $\mathrm{p} 85$ associated with IRS-2 under basal conditions was decreased in liver of Ames dwarf mice $(51 \pm 13$ vs $31 \pm 8 \%$ for normal and dwarf mice respectively, $P<0 \cdot 05)$. As a result of this change, although the amount of $\mathrm{p} 85$ associated with IRS-2 after insulin stimulation in dwarf mice reached values which were not significantly different from those detected in the normal group $(113 \pm 17 \%$ of normal values, $n=5)$ (Fig. 5C and D), the fold of stimulation of p85-IRS-2 association in response to insulin was increased by $64 \%$ (Fig. 5C and D).

\section{PI 3-kinase activity and p85 protein levels}

In normal mice, a bolus injection of insulin led to a 2.5-fold stimulation of PI 3-kinase activity (Fig. 6A and B). In dwarf mice, PI 3-kinase activity after insulin stimulation accounted for $92 \pm 14 \%$ of the value obtained in the insulin-stimulated normal group $(n=4)$. To determine if the lack of GH and PRL was associated with changes in the total content of $\mathrm{p} 85$ protein, homogenates of liver were immunoblotted with anti-p85 antibodies (Fig. 6C). There was no change in the content of $\mathrm{p} 85$ 
A

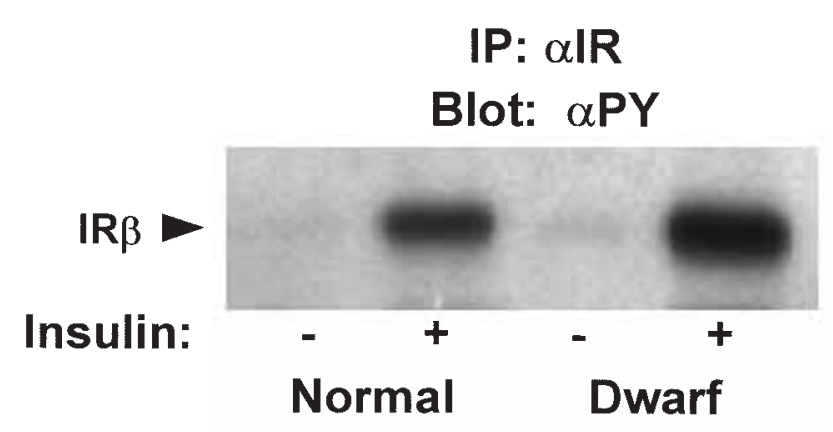

C

IP: $\alpha$ IR

Blot: $\alpha$ IR

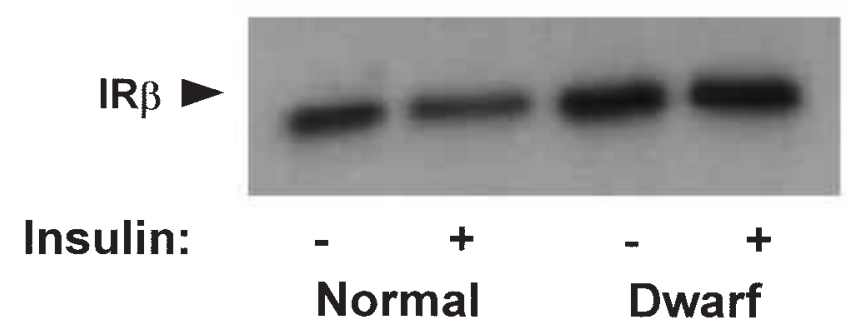

B

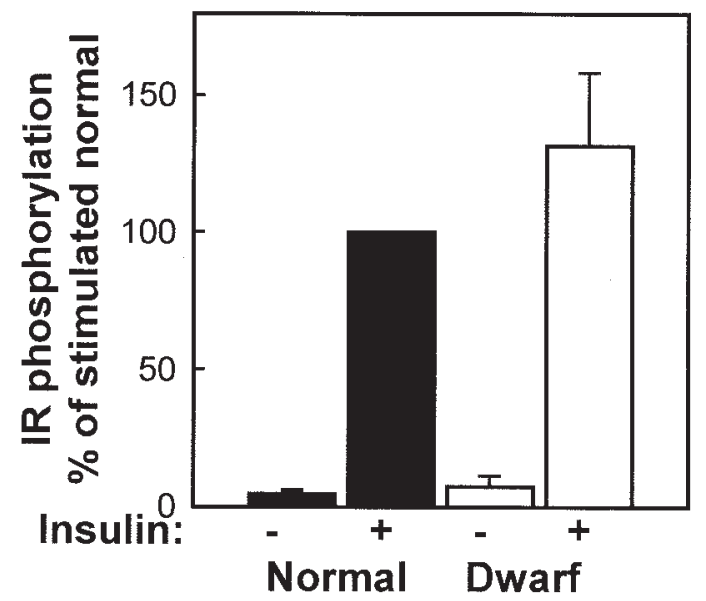

D

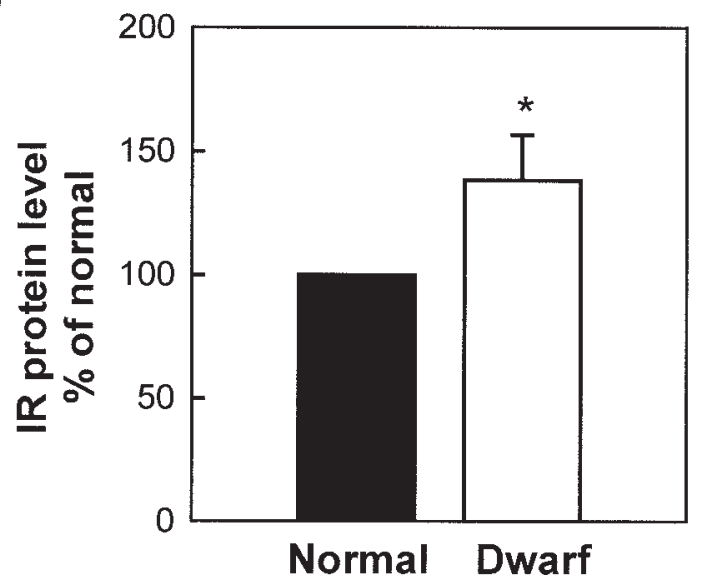

Figure 2 Insulin receptor (IR) tyrosine phosphorylation and abundance in liver of normal and Ames dwarf mice. Animals were injected with saline $(-)$ or insulin $(10 \mathrm{IU} / \mathrm{kg})(+)$ into the portal vein. Equal amounts of solubilized liver protein obtained as described in Materials and Methods were immunoprecipitated (IP) with an $\alpha \mathrm{IR}$, separated by SDS-PAGE, and subjected to immunoblot analysis with $\alpha$ PY (A) and $\alpha I R(C)$. (B and D) Data quantitation by scanning densitometry; means \pm S.E.M. of five different experiments. IR tyrosine phosphorylation is expressed as percentage, assigning a value of $100 \%$ to the mean of insulin-stimulated normal mice (B). IR abundance is expressed as relative to normal values, which were set as $100 \%$ (D). ${ }^{*} P<0 \cdot 01$ compared with normal mice.

protein when Ames dwarf mice were compared with their normal littermates $(n=8$; Fig. $6 \mathrm{D})$.

\section{Akt activation}

In the liver of Ames dwarf mice, insulin-stimulated phosphorylation of Akt at Ser473 was increased to $141 \pm 15 \%$ compared with values measured in normal mice $(n=4, P<0 \cdot 05)$ (Fig. 7A and B). Protein levels of Akt in liver of Ames dwarf mice were similar to those detected in normal mice (Fig. 7C and D).

\section{Discussion}

It has long been determined that anterior pituitary hormones exert a negative modulation of insulin sensitivity (Houssay \& Anderson 1949). Although GH has been 
A

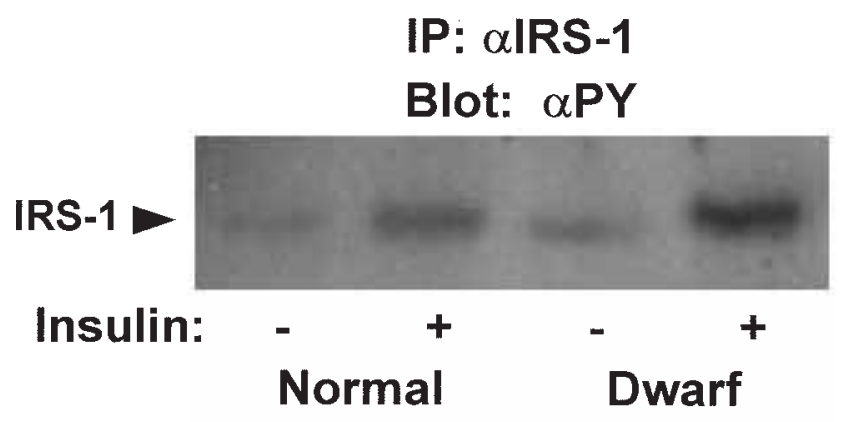

C

IP: $\alpha$ IRS-1

Blot: $\alpha$ IRS-1

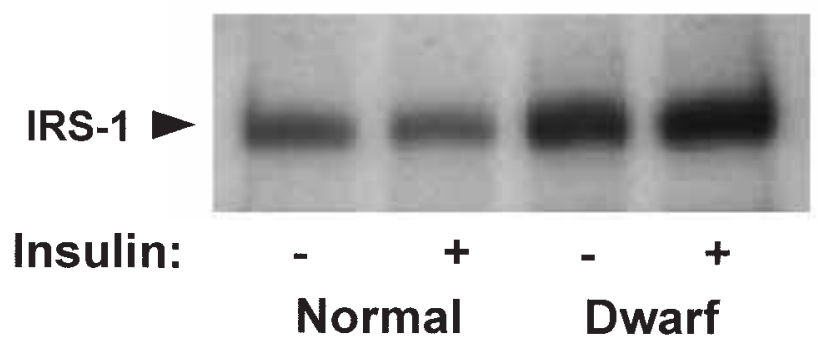

B

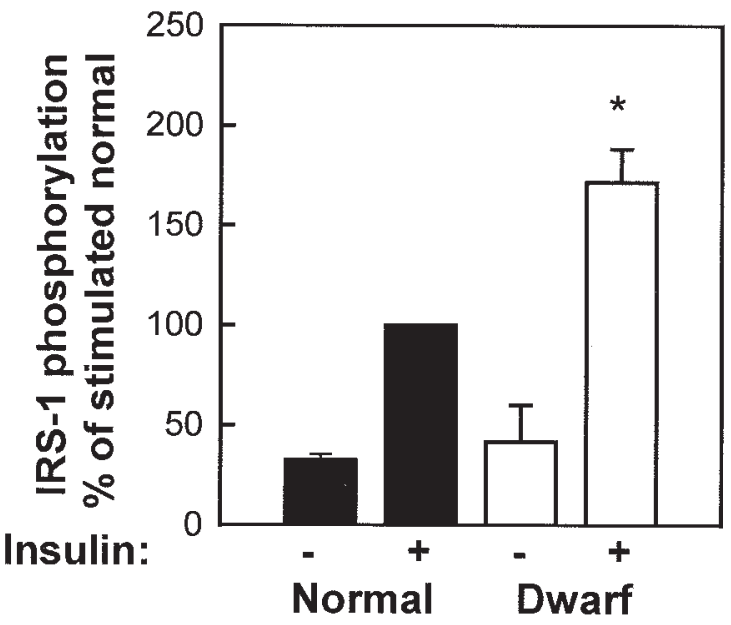

D

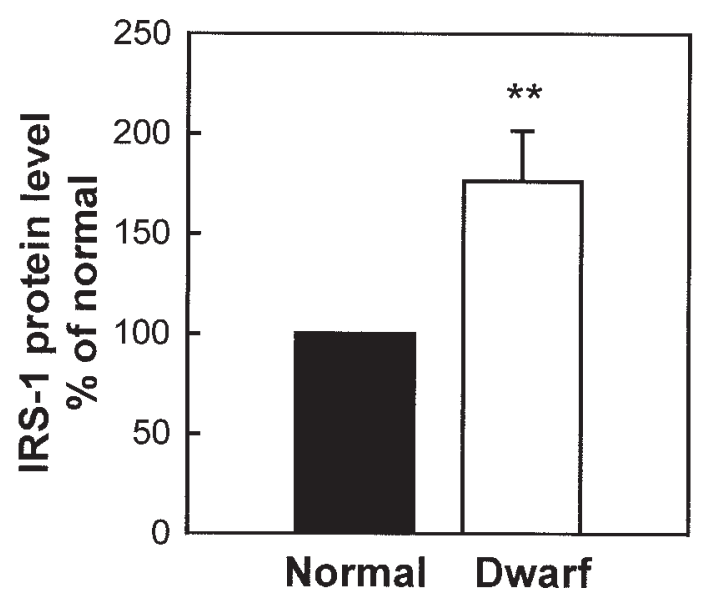

Figure 3 Insulin receptor substrate (IRS)-1 tyrosine phosphorylation and abundance in liver of normal and Ames dwarf mice. Animals were injected with saline $(-)$ or insulin $(10 \mathrm{IU} / \mathrm{kg})(+)$ into the portal vein. Equal amounts of solubilized liver protein obtained as described in Materials and Methods were immunoprecipitated (IP) with $\alpha$ IRS-1, separated by SDS-PAGE, and subjected to immunoblot analysis with $\alpha \mathrm{PY}(\mathrm{A})$ and $\alpha$ IRS-1 (C). (B and D) Data quantitation by scanning densitometry; means \pm S.E.M. of five different experiments. IRS-1 tyrosine phosphorylation is expressed as a percentage, assigning a value of $100 \%$ to the mean of insulin-stimulated normal mice (B). IRS-1 abundance is expressed as relative to normal values, which were set as $100 \%$ (D). ${ }^{\star} P<0 \cdot 01$ and ${ }^{* \star} P<0 \cdot 05$ compared with normal mice.

established to have a primary role in this phenomenon (Davidson 1987), several studies indicate that PRL is also capable of antagonizing insulin action (Landgraf et al. 1977, Schernthaner et al. 1985, Foss et al. 1995, Reis et al. 1997). Increased responsiveness of plasma glucose to insulin in Ames dwarf mice, which are deficient in these hormones, is consistent with the diabetogenic effect of $\mathrm{GH}$ and PRL (Borg et al. 1995). In the fed state, these animals exhibit reduced circulating glucose concentrations, concomitant with normal or slightly reduced circulating insulin levels (Borg et al. 1995). In view of those findings, the present study was conducted to measure sensitivity to exogenous insulin, to examine glucose tolerance and the plasma glucose-insulin relationship further, and to investigate possible changes in the first steps of the insulin signaling pathway in liver of Ames dwarf mice.

Both glucose and insulin circulating concentrations were markedly reduced in Ames dwarf mice after an overnight fast. In addition, these animals exhibited a significantly improved hypoglycemic response to exogenous insulin, which clearly indicates a state of hypersensitivity to insulin. We found that Ames dwarf 
A

IP: $\alpha$ IRS-2

Blot: $\alpha P Y$

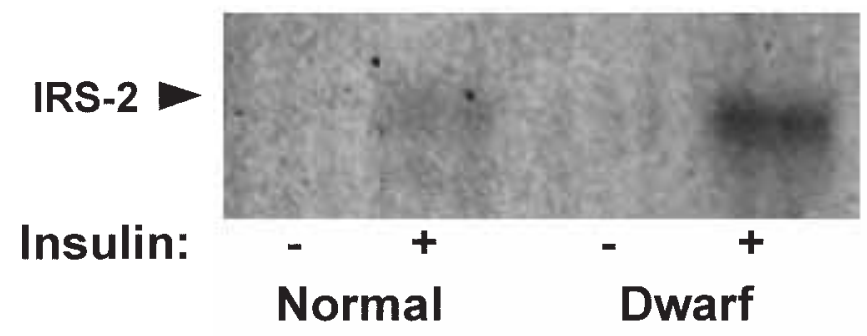

C

IP: $\alpha$ IRS-2

Blot: $\alpha$ IRS-2

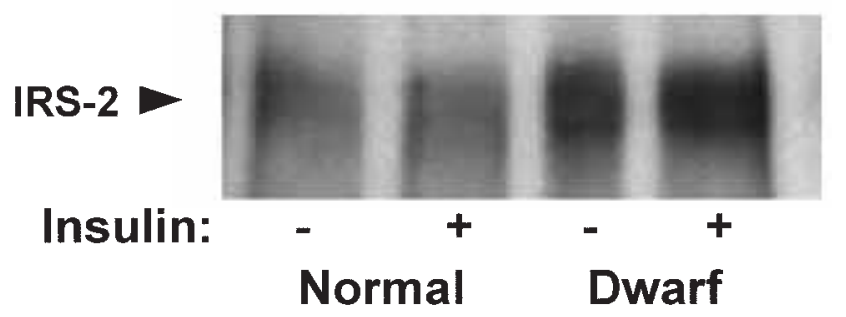

B
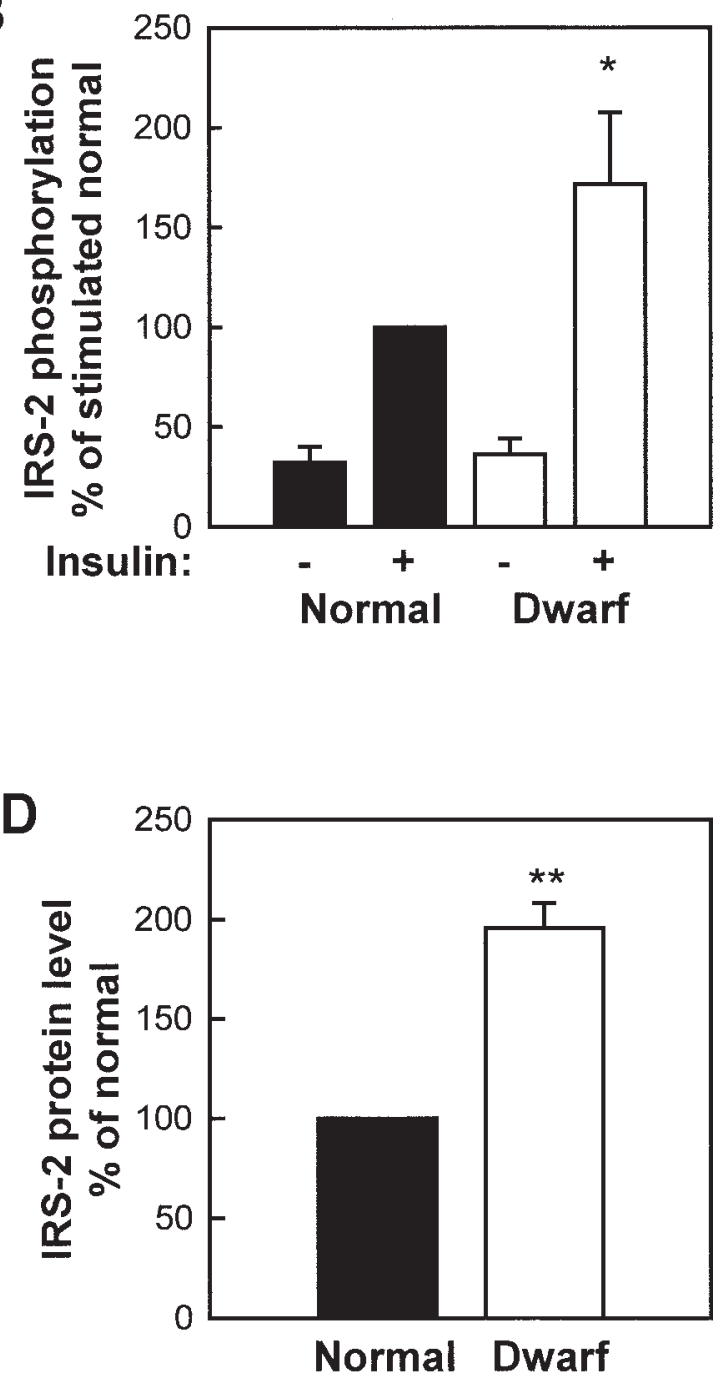

Figure 4 IRS-2 tyrosine phosphorylation and abundance in liver of normal and Ames dwarf mice. Animals were injected with saline ( - ) or insulin $(10 \mathrm{IU} / \mathrm{kg})(+)$ into the portal vein. Equal amounts of solubilized liver protein obtained as described in Materials and Methods were immunoprecipitated (IP) with $\alpha$ IRS-2, separated by SDS-PAGE, and subjected to immunoblot analysis with $\alpha$ PY (A) and $\alpha$ IRS-2 (C). (B and D) Data quantitation by scanning densitometry; means \pm S.E.M. of five different experiments. IRS-2 tyrosine phosphorylation is expressed as a percentage, assigning a value of $100 \%$ to the mean of insulin-stimulated normal mice (B). IRS-2 abundance is expressed as relative to normal values, which were set as $100 \%$ (D). ${ }^{*} P<0 \cdot 05$ and ${ }^{* *} P<0 \cdot 001$ compared with normal mice.

mice displayed a marked intolerance to a glucose load. This result most probably reflects a reduction in the production of insulin from the pancreas, since the acute insulin secretory response to the glucose load was almost blunted in these animals. In addition, previous studies have shown that the total volume of the islets of Langerhans is decreased in Ames dwarf mice (Parsons et al. 1995). This state of increased responsiveness of plasma glucose to insulin concomitant with glucose intolerance bears a resemblance to that exhibited by GH-receptor knockout (GHR-KO) mice in which GH action is precluded (Dominici et al. 2000). The enhanced insulin sensitivity in
GHR-KO mice occurs in the face of a significant increase in circulating PRL concentration (Chandrashekar et al. 1999), which suggests that the effect of GH on insulin action is predominant over that of PRL. Thus, it can be inferred that the changes in the sensitivity to insulin detected in Ames dwarf mice are predominantly induced by the deficiency of GH and not by that of PRL, although this should be determined by selective hormone replacement.

To investigate whether the changes in insulin sensitivity detected in Ames dwarf mice are associated with changes in the insulin signaling pathway, we have analyzed the 
A

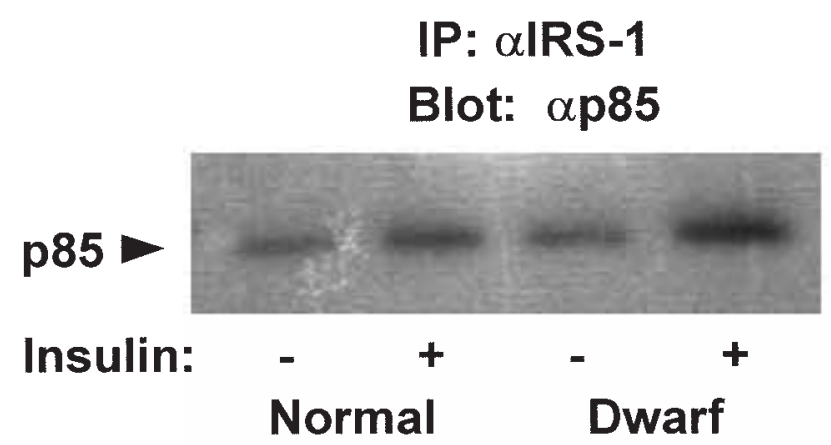

C

IP: $\alpha$ IRS-2

Blot: $\alpha p 85$

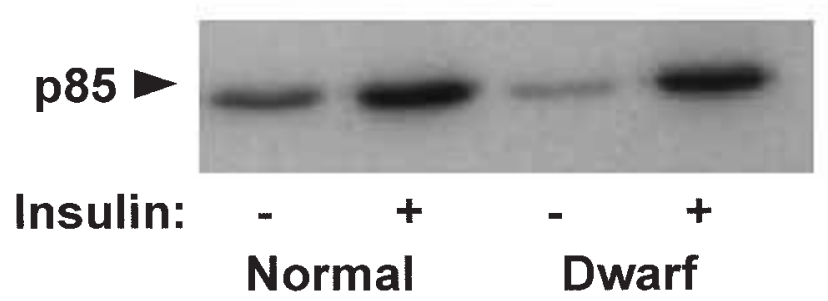

B

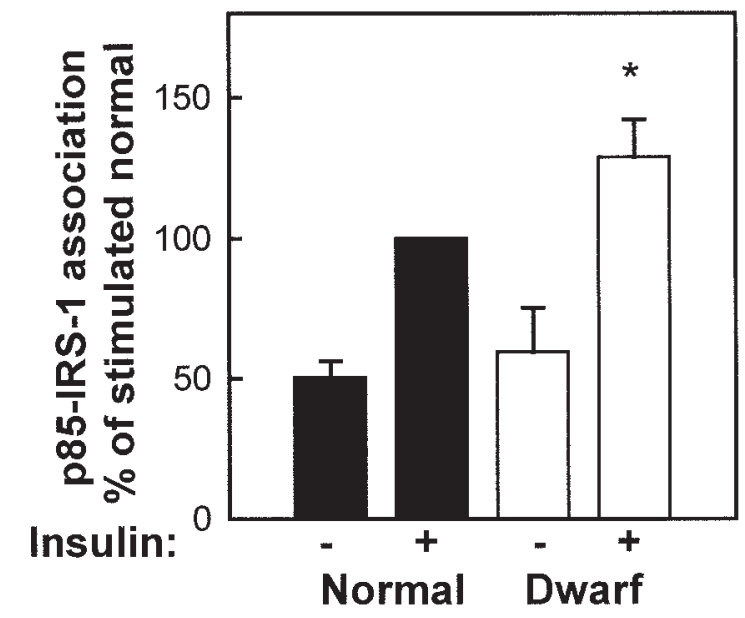

D

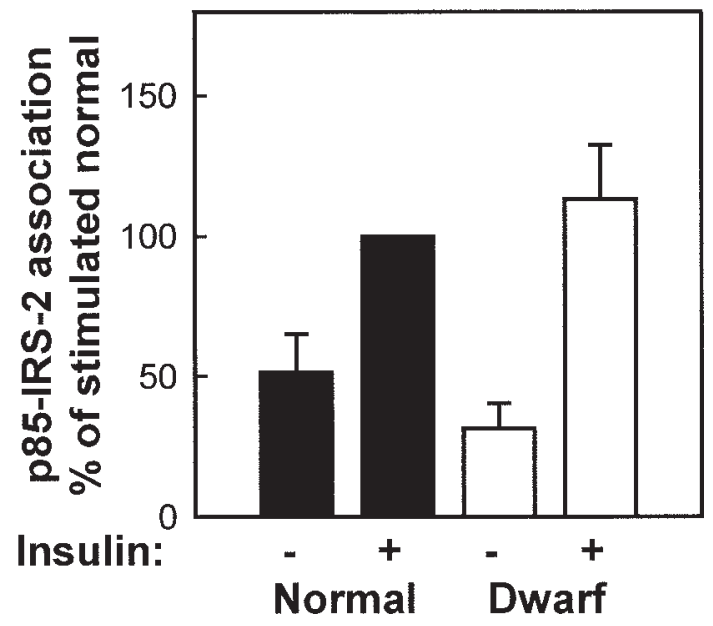

Figure 5 Association of IRS-1 and IRS-2 with p85 in liver of normal and Ames dwarf mice. Animals were injected as described in Figs 3 and 4. Equal amounts of liver protein were subjected to immunoprecipitation with $\alpha$ IRS-1 (A) and $\alpha$ IRS-2 (B), separated by SDS-PAGE, and subjected to immunoblot analysis with ap85. (B and D) Scanning densitometry on autoradiograms from five separate experiments $(n=5$ /group); means \pm S.E.M. expressed as relative to normal assigning a value of $100 \%$ to the mean value in insulin-stimulated normal mice. ${ }^{*} P<0 \cdot 05$ compared with normal mice.

status of the first steps of the insulin signaling system in the liver of Ames dwarf mice. Comparison of the phenotypes of mice with tissue-specific disruption of the IR gene indicates that insulin signaling in liver is critical in glucose homeostasis (Bruning et al. 1998, Michael et al. 2000).

A significant increase in the levels of IR protein was detected in liver of Ames dwarf mice. It is well established that insulin is able to regulate the level of its own receptor (Gavin et al. 1974, Kahn et al. 1978). Upregulation of IR has also been found in hepatocytes of Snell dwarf mice, which have the same endocrine phenotype as Ames dwarfs (Fouchereau-Peron et al. 1980). Since a direct relationship between insulin sensitivity and IR number in liver has been previously established in mouse models of GH excess 

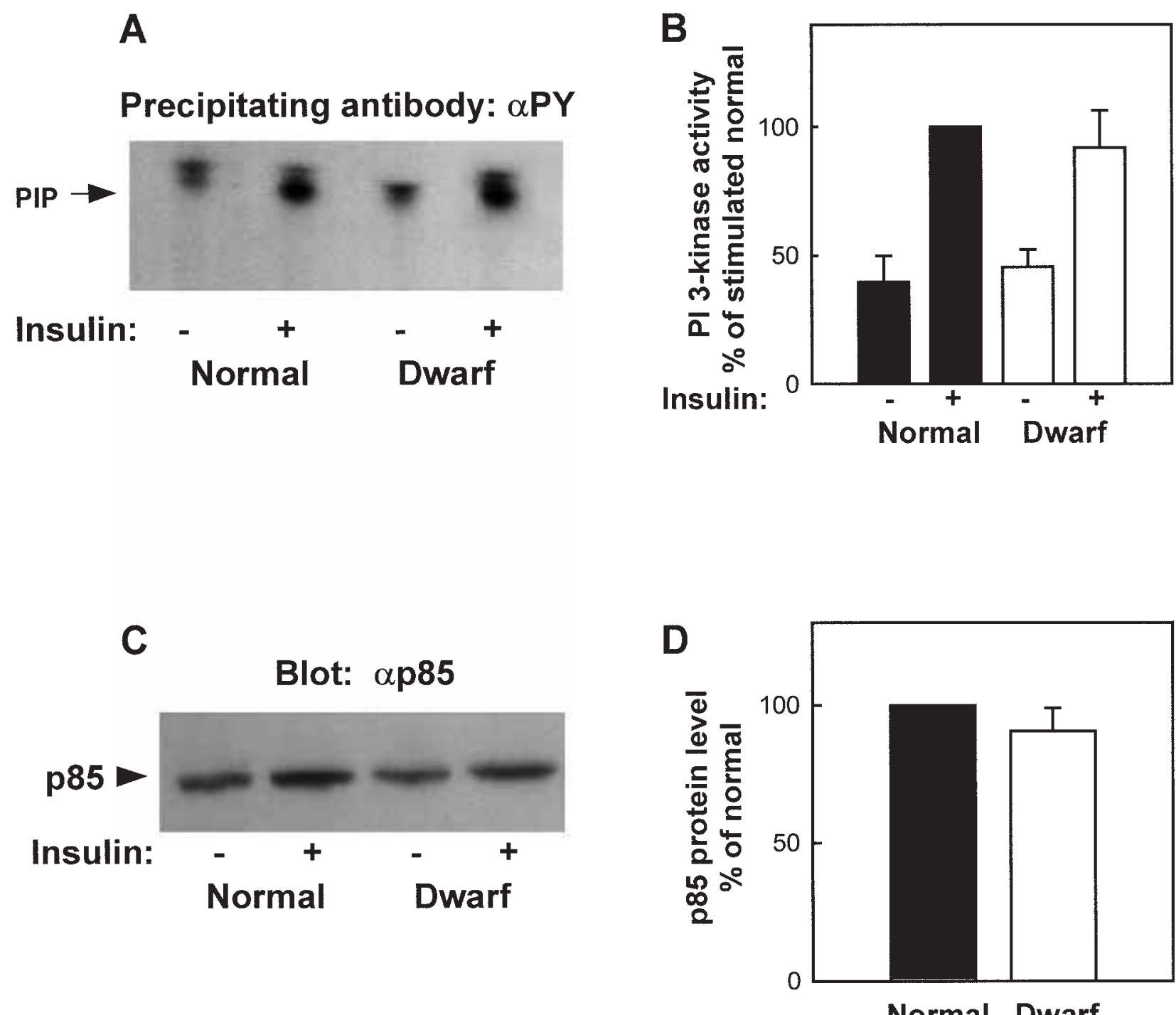

Figure 6 Phosphotyrosine-associated phosphatidylinositol (PI) 3-kinase activity and total content of p85 in liver of normal and Ames dwarf mice. PI 3-kinase was determined in $\alpha$ PY immunoprecipitates as described in Materials and Methods (A). (B) Values are expressed as relative to normal, assigning a value of $100 \%$ to the mean value in insulin-stimulated normal mice. Data are means \pm S.E.M. of four separate experiments ( $n=4$ /group). (C) Aliquots from liver extracts containing equal amounts of protein were separated by SDS-PAGE and immunoblotted with ap85 as described in Materials and Methods. (D) Quantitation of p85 abundance by scanning densitometry; means \pm S.E.M. of four independent experiments ( $n=8 /$ group).

and GH deficiency (Kahn et al. 1978, Dominici et al. 1998, 2000), and expression of IR in the liver is essential for the regulation of glucose disposal (Michael et al. 2000), our present results suggest that the increase in insulin sensitivity in Ames dwarf mice may be accounted for, at least partly, by the increase in the content of IR in the liver detected in these animals. The level of autophosphorylation of the IR on tyrosine residues has a direct relationship with its tyrosine kinase activity towards intracellular substrates (White 1997). Thus, our current results suggest that the tyrosine kinase activity of the IR should be normal or slightly increased in the liver of Ames dwarf mice. Consistent with this observation, although the levels of insulin-stimulated phosphorylation of IRS-1 and IRS-2 were significantly increased, when the data where corrected for the change in the relative protein content of IRS-1 and IRS-2 in liver, the corresponding phosphorylation values were found to be unaltered. Previous studies have indicated that the level of phosphorylation of IRS-1 in vivo depends more on IR kinase activity than on IRS-1 protein levels (Saad et al. 1992, Dominici et al. 1999a). Results from the present study reinforce this 
A

Blot: $\alpha$ phospho-Akt (Ser473)

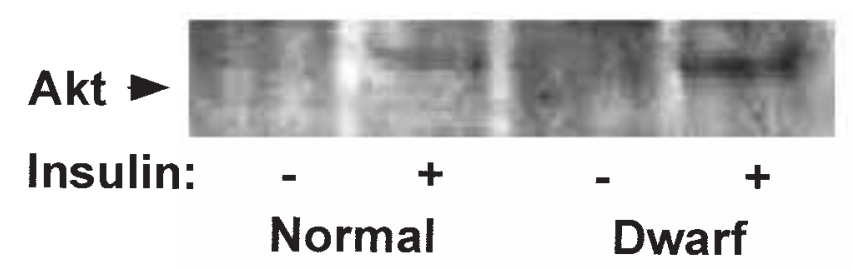

B

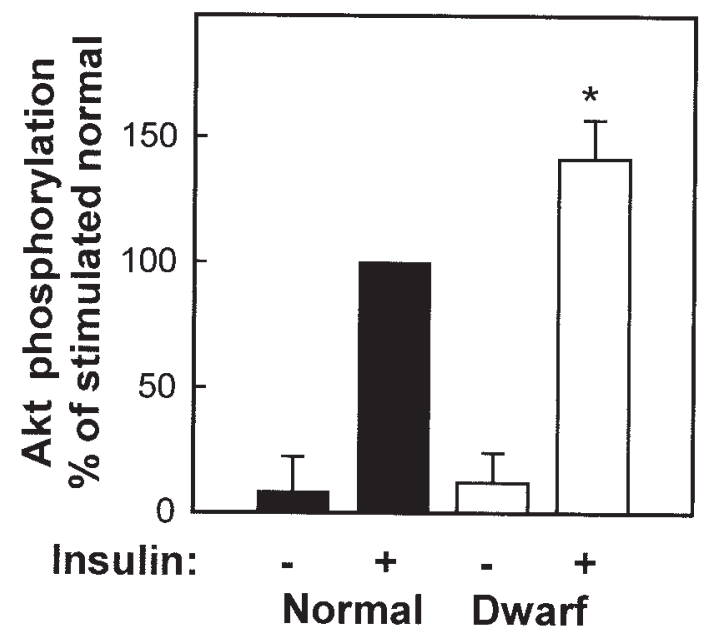

Blot: $\alpha$ Akt

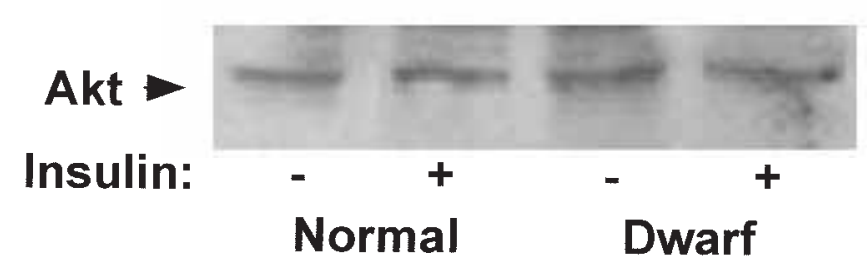

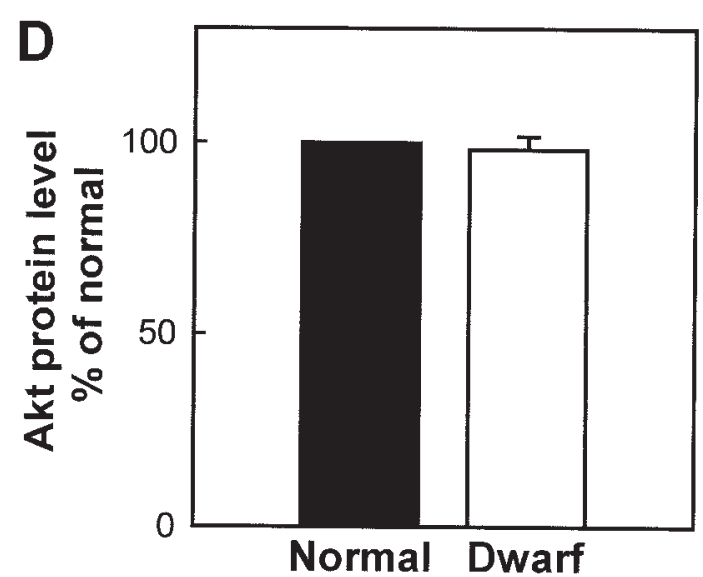

Figure 7 Akt phosphorylation and abundance in liver of normal and Ames dwarf mice. Animals were injected i.v. with insulin. Equal amounts of liver protein were subjected to SDS-PAGE and immunoblot analysis with specific antibodies against Akt-Ser473 (aphospho-Akt) (A). (B) Data quantitation by scanning densitometry; means \pm S.E.M. of four separate experiments $(n=4 /$ group). Values are expressed as a percentage, assigning a value of $100 \%$ to the mean value in insulin-stimulated normal mice. ${ }^{*} P<0 \cdot 05$ compared with normal mice. (C) The same membranes were reprobed with $\alpha$ Akt. (D) Band intensities were quantitated by scanning densitometry; means \pm S.E.M. of four different experiments ( $n=8$ /group), expressed as relative to normal values, which were set as $100 \%$.

observation and suggest that it may also be extended to the in vivo phosphorylation of IRS-2.

The present data indicate that both IRS-1 and IRS-2 are upregulated in liver of Ames dwarf mice, although to a different extent. Nonetheless, this result suggests that the regulation of IRS-1 and IRS-2 in dwarf mice could be coordinated. Recent studies have demonstrated that IRS-2 is more important than IRS-1 in mediating insulin action in liver (Previs et al. 2000). Therefore, upregulation of IRS-2 detected in Ames dwarf mice may play a role in the hypersensitivity to insulin exhibited by these animals. A negative correlation between IRS-1 content and insulin concentrations has been observed in vitro (Saad et al. 1995), and in vivo (Saad et al. 1992). IRS-2 was also found to be downregulated in liver of hyperinsulinemic $o b / o b$ mice (Kerouz et al. 1997). An additional factor influencing IRS-1 and IRS-2 expression in liver of Ames dwarf mice could be the deficiency of GH and PRL. Recent studies demonstrated that IRS-1 and IRS-2 participate in the signaling pathways of both GH and PRL in liver (Yamauchi et al. 1998, Thirone et al. 1999). In a previous study, we have shown that the level of IRS-1 is unaltered in liver of GHR-KO mice (Dominici et al. 2000). In these GH-resistant animals, PRL circulating concentrations are 
substantially increased (Chandrashekar et al. 1999), which may result in enhanced PRL signaling. This led us to postulate that the increased utilization of IRS-1 by the PRL receptor in these GH-resistant mice could compensate for the lack of GHR utilization of IRS-1 (Dominici et al. 2000). Our present results agree with this hypothesis, and suggest that the simultaneous lack of GH and PRL in Ames dwarf mice may result in an increase in the expression of IRS-1 and IRS-2 in liver to compensate for the simultaneous deficiency of the actions of these two hormones. Besides being deficient in GH and PRL, Ames dwarf mice are also hypothyroid (Bartke 1979). Although increased insulin sensitivity has been reported to be associated with states of hypothyroidism in some studies (Shah et al. 1975, Matthaei et al. 1995), we are not aware of any evidence associating hypothyroidism with a change in the levels of the IRS proteins.

Consistent with the increase in tyrosine phosphorylation, the association of $\mathrm{p} 85$ with IRS-1 after insulin stimulation was increased in liver of Ames dwarf mice. The reduction in the amount of $\mathrm{p} 85$ associated with IRS-2 in dwarf mice under basal conditions could be the result of the large increase in the levels of IRS-2 protein, which was not followed by an equal change in the amount of $\mathrm{p} 85$ in this tissue. The activity of PI 3-kinase associated with phosphotyrosine was unaltered in dwarf mice and therefore paralleled more closely the level of association of $\mathrm{p} 85$ with IRS-2 than that exhibited with IRS-1. This result is consistent with previous observations which indicated that IRS-2 is the major mediator of insulin signaling in the liver (Withers et al. 1998, Previs et al. 2000).

Our current results indicate that the increased insulin sensitivity exhibited by Ames dwarf mice is not the result of changes in PI 3-kinase activity in the liver. This result is somewhat unexpected. In several in vivo studies, reduced insulin sensitivity has been found to be associated with impaired activation of PI 3-kinase by insulin in liver (Folli et al. 1993, Saad et al. 1993, Kerouz et al. 1997, Withers et al. 1998, Dominici et al. 1999b). Based on those observations, we hypothesized that, in parallel to enhanced insulin sensitivity, the insulin-stimulated PI 3-kinase activity should have been increased in liver of Ames dwarf mice. However, in recent studies, coexistence of reduced insulin sensitivity with enhanced insulin activation of PI 3-kinase in the liver was demonstrated (Anai et al. 1999, Ogihara et al. 2001). Conversely, in a previous study we have demonstrated the coexistence of hypersensitivity to insulin with normal PI 3-kinase activity in the liver of GHR-KO mice (Dominici et al. 2000). Together with results from those previous studies, our present results suggest that the in vivo level of insulin-stimulated activity of PI 3-kinase in liver does not always parallel the insulin sensitivity status. Interestingly, Akt phosphorylation at Ser473 was increased, suggesting that GH, PRL and TSH deficiency leads to a PI 3-kinase-indepent activation of Akt in this mouse model. Moreover, the increase in Akt phosphorylation suggests that the increment in IR, IRS-1 and IRS-2 protein has physiological significance, since this Ser/Thr kinase has been implicated in mediating insulin responses (Coffer et al. 1998).

In summary, this study demonstrates that the deficiency of GH, PRL and TSH is associated with increased insulin sensitivity in Ames dwarf mice. This metabolic alteration is associated with changes in insulin signaling in liver, which include increased protein levels of IR, IRS-1 and IRS-2, increased insulin-stimulated phosphorylation of IRS-1 and IRS-2, enhanced insulin-stimulated association of p85 with IRS-1 and IRS-2, and increased insulininduced Akt activation through a PI 3-kinase-independent mechanism. These compensatory changes in insulin signaling in liver may have an important role in the phenotype of Ames dwarf mice. Moreover, it is interesting to point out that these animals live much longer than their normal siblings (Brown-Borg et al. 1996) and that alterations in insulin signaling or in homologous pathways have been associated with increased longevity in the fruit fly Drosophila melanogaster (Clancy et al. 2001, Tatar et al. 2001) and in other organisms (Kimura et al. 1997).

\section{Acknowledgements}

We are grateful to D Pazo for help with the glucose and insulin tolerance tests and Dr J Mattison for her invaluable support. D T is a Career Investigator from Consejo Nacional de Investigaciones Científicas y Tecnológicas of Argentina (CONICET), received grant support from the University of Buenos Aires, and CONICET, and is a recipient of a Ramón Carrillo-Oñativia Fellowship from Ministerio de Salud de la Nación of Argentina. A B received support from the Illinois Council on Food and Agricultural Research. FPD is a recipient of a postdoctoral research fellowship from CONICET.

\section{References}

Ader M, Agajanian T, Finegood DT \& Bergman RN 1987 Recombinant deoxyribonucleic acid-derived $22 \mathrm{~K}$ - and $20 \mathrm{~K}$-human growth hormone generate equivalent diabetogenic effects during chronic infusion in dogs. Endocrinology 120 725-731.

Alessi DR, Andjelkovic M, Caudwell B, Cron P, Morrice N, Cohen P \& Hemmings BA 1996 Mechanism of activation of protein kinase B by insulin and IGF-I. EMBO Journal 15 6541-6551.

Anai M, Funaki M, Ogihara T, Kanda A, Onishi Y, Sakoda H, Inukai K, Nawano M, Fukushima Y, Yazaki Y, Kikuchi M, Oka Y \& Asano T 1999 Enhanced insulin-stimulated activation of phosphatidylinositol 3-kinase in the liver of high-fat-fed rats. Diabetes 48 158-169.

Andersen B, Pearse RV, Jenne K, Sornson M, Lin SC, Bartke A \& Rosenfeld MG 1995 The Ames dwarf gene is required for Pit-1 gene activation. Developmental Biology 172 495-503.

Araki E, Lipes MA, Patti MA, Bruning JC, Haag B, Johnson RS \& Kahn CR 1994 Alternative pathway of insulin signaling in mice with target disruption of the IRS-1 gene. Nature 372 186-190. 
Argetsinger LS, Hsu GW, Myers MG Jr, Billestrup N, White MF \& Carter-Su C 1995 Growth hormone, interferon-gamma, and leukemia inhibitory factor promoted tyrosyl phosphorylation of insulin receptor substrate-1. Journal of Biological Chemistry 270 14685-14692.

Backer JM, Myers MG Jr, Shoelson SE, Chin DJ, Sun XJ, Miralpeix M, Hu P, Margolis B, Skolnik EY, Schlessinger J \& White MF 1992 Phosphatidylinositol $3^{\prime}$-kinase is activated by association with IRS-1 during insulin stimulation. EMBO Journal 11 3469-3479.

Bartke A 1979 Genetic models in the study of anterior pituitary hormones. In Genetic Variation in Hormone Systems, pp 113-126. Ed. JGM Shire. Boca Raton, FL: CRC Press.

Berlanga JJ, Gualillo O, Buteau H, Applanat M, Kelly PA \& Edery M 1997 Prolactin activates tyrosyl phosphorylation of insulin receptor substrate 1 and phosphatidylinositol 3-OH kinase. Journal of Biological Chemistry 272 2050-2052.

Borg KE, Brown-Borg HM \& Bartke A 1995 Assessment of the primary adrenal cortical and pancreatic hormone basal levels in relation to plasma glucose and age in the unstressed Ames dwarf mouse. Proceedings of the Society for Experimental Biology and Medicine $210126-133$.

Bougneres PF, Artavia-Loria E, Ferre P, Chaussain J-L \& Job L-C 1985 Effect of hypopituitarism and growth hormone replacement therapy on the production and utilization of glucose in childhood. Journal of Clinical Endocrinology and Metabolism 61 1152-1157.

Brown-Borg H, Borg K, Meliska C \& Bartke A 1996 Dwarf mice and the aging process Nature 38433.

Bruning JC, Michael MD, Winnay JN, Hayashi T, Horsch D, Accili D, Goodyear LJ \& Kanh CR 1998 A muscle-specific insulin receptor knockout exhibit features of the metabolic syndrome of NIDDM without altering glucose tolerance. Molecular Cell 2 559-569.

Chandrashekar V, Bartke A, Coschigano KT \& Kopchick JJ 1999 Pituitary and testicular function in growth hormone receptor gene knockout mice. Endocrinology 140 1082-1088.

Cheatham B \& Kahn CR 1995 Insulin action and the insulin signaling network. Endocrine Reviews 16 117-142.

Clancy DJ, Gems D, Harshman LG, Oldham S, Stocker H, Hafen E, Leevers SJ \& Partridge L 2001 Extension of life span by loss of CHICO, a Drosophila insulin receptor substrate protein. Science $\mathbf{2 9 2}$ 104-106.

Coffer PJ, Jin J \& Woodget JR 1998 Protein kinase B (c-Akt): a multifunctional mediator of phosphatidylinositol 3-kinase activation. Biochemical Journal 335 1-13.

Daugaard JR, Lausten JL, Hanten BS \& Richter EA 1999 Insulin action in growth hormone-deficient and age-matched control rats: effect of growth hormone treatment. Journal of Endocrinology 160 $127-135$.

Davidson MB 1987 Effect of growth hormone on carbohydrate and lipid metabolism. Endocrine Reviews 8 115-131.

Dominici FP, Balbis A, Bartke A \& Turyn D 1998 Role of hyperinsulinemia on hepatic insulin receptor concentration and autophosphorylation in the presence of high growth hormone levels in transgenic mice overexpressing GH gene. Journal of Endocrinology 159 15-25.

Dominici FP, Cifone D, Bartke A \& Turyn D 1999a Loss of sensitivity to insulin at early events of the insulin signaling pathway in the liver of growth hormone-transgenic mice. Journal of Endocrinology 161 383-392.

Dominici FP, Cifone D, Bartke A \& Turyn D 1999b Alterations in early steps of the insulin-signaling system in skeletal muscle of GH-transgenic mice. American Journal of Physiology 277 E447-E454.

Dominici FP, Arostegui Diaz G, Kopchick JJ, Bartke A \& Turyn D 2000 Compensatory alterations of insulin signal transduction in liver of growth hormone receptor knockout mice. Journal of Endocrinology $166579-590$.
Folli F, Saad MJ, Backer JM \& Kahn CR 1993 Regulation of phosphatidylinositol 3-kinase activity in liver and muscle of animal models of insulin-resistant and insulin-deficient diabetes mellitus. Journal of Clinical Investigation 92 1787-1794.

Foss MC, Paula FJ, Paccola GM \& Piccinato CE 1995 Peripheral glucose metabolism in human hyperprolactinemia. Clinical Endocrinology 43 721-726.

Fouchereau-Peron M, Broer Y \& Rosselin G 1980 Growth hormone and insulin binding to isolated hepatocytes in the genetically dwarf mouse. Biochimica et Biophysica Acta 631 451-462.

Gavin JR III, Roth J, Neville DM Jr, De Meyts P \& Buell DN 1974 Insulin-dependent regulation of insulin receptor concentrations: a direct demonstration in cell culture. PNAS 71 84-88.

Hopwood NJ, Forsman PJ, Kenny FM \& Drash AL 1975 Hypoglycemia in hypopituitary children. American Journal of Diseases of Childhood 129 918-929.

Houssay BA \& Anderson E 1949 Diabetogenic action of purified anterior pituitary hormones. Endocrinology 45 627-629.

Kahn CR, Goldfine ID, Neville DM Jr \& Demeyts P 1978 Alterations in insulin binding induced by changes in vivo in the levels of glucocorticoids and growth hormone. Endocrinology 103 1054-1066.

Kerouz NJ, Horsch D, Pons S \& Kahn CR 1997 Differential regulation of insulin receptor substrates- 1 and -2 (IRS-1 and IRS-2) and phosphatidylinositol 3-kinase in liver and muscle of the obese diabetic (ob/ob) mouse. Journal of Clinical Investigation 100 3164-3172.

Kimura KD, Tissenbaum HA, Liu Y \& Ruvkun G 1997 daf-2, an insulin receptor-like gene that regulates longevity and diapause in Caenorhabditis elegans. Science 277 897-898.

Landgraf R, Landraf-Leurs MM, Weissmann A, Horl R, von Werder K \& Scriba PC 1977 Prolactin: a diabetogenic hormone. Diabetologia 13 99-104.

Matthaei S, Trost B, Hamann A, Kausch C, Benecke H, Greten H, Hoppner W \& Klein HH 1995 Effect of in vivo thyroid status on insulin signalling and GLUT1 and GLUT4 glucose transport systems in rat adipocytes. Journal of Endocrinology 144 347-357.

Michael MD, Kulkarni RN, Postic C, Previs SF, Shulman GI, Magnuson MA \& Kahn CR 2000 Loss of insulin signaling in hepatocytes leads to severe insulin resistance and progressive hepatic dysfunction. Molecular Cell 6 87-97.

Ogihara T, Asano T, Ando K, Chiba Y, Sekine N, Sakoda H, Anai M, Onishi Y, Fujishiro M, Ono H, Shojima N, Inukai K, Fukushima Y, Kikuchi M \& Fujita T 2001 Insulin resistance with enhanced insulin signaling in high-salt diet-fed rats. Diabetes $\mathbf{5 0}$ 573-583.

Parsons JA, Bartke A \& Sorenson RL 1995 Number and size of islets of Langerhans in pregnant, human growth hormone-expressing transgenic, and pituitary dwarf mice: effect of lactogenic hormones. Endocrinology 136 2013-2021.

Previs SF, Withers DJ, Ren JM, White MF \& Shulman GI 2000 Contrasting effects of IRS-1 versus IRS-2 gene disruption on carbohydrate and lipid metabolism in vivo. Journal of Biological Chemistry 275 38990-38994.

Reis FM, Reis AM \& Coimbra CC 1997 Effects of hyperprolactinemia on glucose tolerance and insulin release in male and female rats. Journal of Endocrinology 153 423-428.

Ridderstråle M, Degerman E \& Tornqvist H 1995 Growth hormone stimulates the tyrosine phosphorylation of the insulin receptor substrate-1 and its association with phosphatidylinositol 3-kinase in primary adipocytes. Journal of Biological Chemistry 270 3471-3474.

Rizza RA, Mandarino LJ \& Gerich JE 1982 Effects of growth hormone on insulin action in man. Mechanisms of insulin resistance, impaired suppression of glucose production, and impaired stimulation of glucose utilization. Diabetes 31 663-669. 
Saad MJ, Araki E, Miralpeix M, Rothenberg PL, White MF \& Kahn CR 1992 Regulation of insulin receptor substrate-1 in liver and muscle of animal models of insulin resistance. Journal of Clinical Investigation 90 1839-1849.

Saad MJA, Folli F, Kahn JA \& Kahn CR 1993 Modulation of insulin receptor, insulin receptor substrate-1, and phosphatidylinositol 3 -kinase in liver and muscle of dexamethasone-treated rats. Journal of Clinical Investigation 92 2065-2072.

Saad MJ, Folli F \& Kahn CR 1995 Insulin and dexamethasone regulate insulin receptors, insulin receptor substrate-1, and phosphatidylinositol 3-kinase in Fao hepatoma cells. Endocrinology 136 1579-1588.

Schaible R \& Gowen JW 1961 A new dwarf mouse. Genetics 46896.

Schernthaner G, Prager R, Punzengruber C \& Luger A 1985 Severe hyperprolactinemia is associated with decreased insulin binding in vitro and insulin resistance in vivo. Diabetologia 28 138-142.

Shah JH, Motto GS, Papagiannes E \& Williams GA 1975 Insulin metabolism in hypothyroidism. Diabetes 24 922-925.

Shepherd PR, Withers DJ \& Siddle K 1998 Phosphoinositide 3-kinase: the key switch mechanism in insulin signalling. Biochemical Journal 333 471-490.

Souza SC, Frick PG, Yip R, Lobo RB, Tai LR \& Goodman HM 1994 Growth hormone stimulates tyrosine phosphorylation of insulin receptor substrate-1. Journal of Biological Chemistry 269 30085-30088.

Sun XJ, Wang LM, Zhang Y, Yenush L, Myers MJ, Glasheen E, Lane WS, Pierce JH \& White MF 1995 Role of IRS-2 in insulin and cytokine signalling. Nature 377 173-177.
Tamemoto H, Kadowaki T, Tobe K, Yagi T, Sakura H, Hayakawa T, Terauchi Y, Ueki K, Kaburagi Y, Satoh S, Sekchara H, Yoshioka S, Horikoshi H, Furuta Y, Ikawa Y, Kasuga M, Yazaki Y \& Aizawa S 1994 Insulin resistance and growth retardation in mice lacking insulin receptor substrate-1. Nature 372 182-186.

Tatar M, Kopelman A, Epstein D, Tu MP, Yin CM \& Garofalo RS 2001 A mutant Drosophila insulin receptor homolog that extends life and impairs neuroendocrine function. Science 292 107-110.

Thirone ACP, Carvalho CRO \& Saad MJA 1999 Growth hormone stimulates the tyrosine kinase activity of JAK2 and induces tyrosine phosphorylation of insulin receptor substrates and SHC in rat tissues. Endocrinology 140 55-62.

White MF 1997 The insulin signalling system and the IRS proteins. Diabetologia 40 S2-S17.

Withers DJ, Gutierrez JS, Towery H, Burks DJ, Ren JM, Previs S, Zhang Y, Bernal D, Pons S, Shulman GI, Bonner-Weir S \& White MF 1998 Disruption of IRS-2 causes type 2 diabetes in mice. Nature 391 900-904.

Yamauchi T, Kaburagi Y, Ueki K, Tsuji Y, Stark GR, Kerr IM, Tsushima T, Akanuma Y, Komuro I, Tobe K, Yazaki Y \& Kadowaki T 1998 Growth hormone and prolactin stimulate tyrosine phosphorylation of insulin receptor substrate-1, -2 and -3 , their association with $\mathrm{p} 85$ phosphatidylinositol 3-kinase (PI3-kinase) and concomitantly PI3-kinase activation via JAK2 kinase. Journal of Biological Chemistry 273 15719-15726.

Received 26 September 2001

Accepted 5 December 2001 